\title{
Sea level changes during the last and present interglacials in Sal Island (Cape Verde archipelago)
}

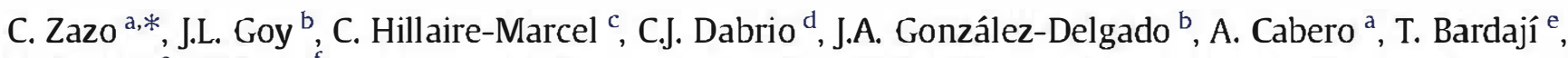 \\ B. Ghaleb ${ }^{c}$, V. Soler ${ }^{f}$ \\ a Departamento de Geología, Museo Nacional de Ciencias Naturales, CSIC, José Gutiérrez Abascal, 2, 28006-Madrid, Spain \\ ${ }^{b}$ Departamento de Geología, Facultad de Ciencias, Universidad de Salamanca, 37008-Salamanca, Spain \\ c GEOTOP-UQAM, Montréal, Canada H3C 3 P8 \\ a Departamento de Estratigrafía, Facultad de Ciencias Geológicas \& Instituto de Geología Económica CSIC, Universidad Complutense, 28040-Madrid, Spain \\ - Departamento de Geología, Facultad de Ciencias, Universidad de Alcalá, 28871-Alcalá de Henares, Spain \\ ' Estación Volcanológica de Canarias, CSIC, Avenida Astrofisico Sánchez 3, 38206 La Laguna-Tenerife, Spain
}

Eastern Atlantic last interglacial Holocene

marine terrace barrier island sea level

\begin{abstract}
A B S T R A C T
Last interglacial and Holocene deposits are particularly well developed in the southern parts of Sal Island (Cape Verde Archipelago). They primarily consist of low-elevation ( $\leq 2 \mathrm{~m}$ above sea level [a.s.l.]) marine deposits made of a basal conglomerate embedded in carbonate mud, passing upwards to calcarenites. All deposits contain an abundant fauna with corals, algae and molluscs with Strombus latus Gmelin and accompanying warm water species of the "Senegalese" fauna. Small scale geomorphological mapping with detailed morphosedimentary analysis revealed lateral facies changes and imbricate (offlapping) structures that suggest small-scale oscillations of paleo-sealevels during high sea stand intervals. U-series measurements (in coral fragments) allowed unequivocal identification of Marine Isotope Substage (MIS) 5.5 units, but were not precise enough to date the sea level oscillations of the interval. However, geomorphological data and sedimentary facies analysis suggest a double sea level highstand during the peak of the last interglacial.

MIS 5.5 age deposits occur at Sal and the Canary Islands at low topographic elevations, between 1 and 2 masl. However, these values are lower than the elevations measured for the correlative terraces outcropping at the western tropical Atlantic islands, widely considered to be tectonically stable.

Combining the results in this paper with earlier investigations of the "Senegalese" fauna distribution as far north as the Mediterranean basin, it is suggested that the last-interglacial oceanic temperatures in this basin, as well as the temperatures in other islands of the Eastern Atlantic and the coasts of Morocco, were warmer than modern temperatures.
\end{abstract}

\section{Introduction}

Global high sea levels can be estimated from the elevation of ancient shorelines not only in tectonically stable areas, but also in tectonically uplifted areas provided that constant uplift rates are assumed. For example, in the Western Atlantic Ocean, studies of constructional reef terraces from islands considered tectonically stable (e.g., Bermuda, Bahamas, Western Australia), particularly of terraces generated during the last interglacial (Marine Isotope StageMIS 5), provided relatively precise information about the relative

\footnotetext{
* Corresponding author. Tel.: + 34914111328x1189; fax: + 34915644740. E-mail addresses: mcnzc65@mncn.csic.es (C. Zazo), joselgoy@usal.es (J.L. Goy), chm@uqam.ca (C. Hillaire-Marcel), dabrio@geo.ucm.es (C.J. Dabrio), angel@usal.es (J.A. González-Delgado), acabero@mncn.csic.es (A. Cabero), teresa.bardaji@uah.es (T. Bardají), r13644@er.uqam.ca (B. Ghaleb), vsoler@ipna.csic.es (V. Soler).
}

elevation and duration of high sea stand episodes (Chen et al., 1991; Neumann and Hearty, 1996; Stirling et al., 1998; Hearty, 2002; Muhs, 2002; Muhs et al., 2002; Mylroie, 2007). In a similar fashion, Schellmann and Radtke (2004), and Schellmann et al. (2004) used detailed mapping and a combination of dating methods to discuss and deduce paleo-sea level scenarios during MIS 5.5 in the tectonically active Barbados. Coral terraces of the last interglacial age have been recently studied in Haiti by Dumas et al. (2006) by means of geomorphologic analysis and $\mathrm{Th} / \mathrm{U}$ data.

In contrast with the abundant literature on sea level changes in the western Subtropical Atlantic, there are very few published studies of paleo-sealevels in islands at similar latitudes of the eastern tropical Atlantic. In Cape Verde (Fig. 1), early mentions of three uplifted Quaternary terraces bearing a rich faunal content were made by Lecointre (1962, 1963, 1965) and, recently, Zazo et al. (2007) described several uplifted Quaternary marine terraces in Sal Island. There are studies covering the Canary Islands (Meco et al., 1997, 2002; Zazo et al., 2002, 2003, 2004) and the Atlantic coast of Morocco 
island of the archipelago, as its Monte Grande (Big Mountain) summit only measures $406 \mathrm{~m}$ in elevation. Its climate is tropical-dry, with mean temperatures around $28{ }^{\circ} \mathrm{C}$ in the dry season (November-June), and $19{ }^{\circ} \mathrm{C}$ during the rainy season (August-October). The scarce rainfall (average $\sim 102 \mathrm{~mm} / \mathrm{yr}$ ) occurs during the annual northwards displacement of the Intertropical Convergence Zone (ITCZ), and is too small to feed permanent water courses, making Sal the driest island of the archipelago. The mean average tidal range is $1 \mathrm{~m}$. Volcanic activity in the island occurred from 25.6 Ma to ca. 0.6 Ma (Torres et al., 2002a). The oldest sedimentary rocks identified so far are marine calcarenites of Late Miocene-Pliocene age (Silva et al., 1993; Torres et al., 2002a,b). Quaternary deposits include aeolian, alluvial fan and marine deposits. Broad surfaces associated with cemented marine sediments are locally referred to as Lajedos.

\section{Materials and methods}

\subsection{Mapping and facies analysis}

This paper presents a geomorphologic map (Fig. 2) of the marine, transitional and terrestrial deposits of the southern extremity of Sal (Sheet 29, Sc. 1/25,000 - Santa María of Cabo Verde Topographic Map), based on aerial photograph examination (scale 1:15,000, taken in 1991) and field controls. A 1:10,000 scale was used for the southeastern tip of the island because of the small extension of outcrops (Fig. 3). This map illustrates the occurrence of all morphosedimentary units of the last and present interglacials (Fig. 2). All preMIS 5.5 marine terraces have been represented using the same (blue) colour, although escarpments separating successive terraces have also been indicated.

Facies analysis was applied to all the mapped morpho-sedimentary units, aiming to distinguish shallow marine, beach, lagoon and terrestrial (alluvial and aeolian) coastal facies. This has been seen as essential here, as a means of setting the present topographic elevation of a given marine unit with respect to the modern sea level. The altitude of the inner part of marine edges (coast line angles) was determined using topographic maps as well as altimetric and rod measurements. The topographic elevations of marine terraces refer to modern, mean high tide level. This level is thus used as the $0 \mathrm{~m}$ datum.

\subsection{Palaeontology}

Malacological studies were mostly focused on the identification of species common to Cape Verde and the Mediterranean Sea during the last interglacial. This fauna is known in the Spanish Mediterranean and Atlantic-Mediterranean transition area (Cuerda, 1989; Lario et al., 1993; Alouane, 2001; Zazo et al., 1999, 2003) as the warm "Senegalese" fauna originally defined in the Italian Mediterranean by Gignoux (1913) and Issel (1914). This fauna is characterized by the gastropod Strombus bubonius Lamarck (syn: Strombus latus Gmelin) that colonized the Mediterranean Sea during a time span which these authors called the Tyrrhenian.

For the African coasts, faunal identifications from Lecointre (1965) and Abbott and Dance (2000) were combined with observations of collections from the Musée d'Histoire Naturelle de Paris (France), along with our own data base and earlier papers about the Macaronesian
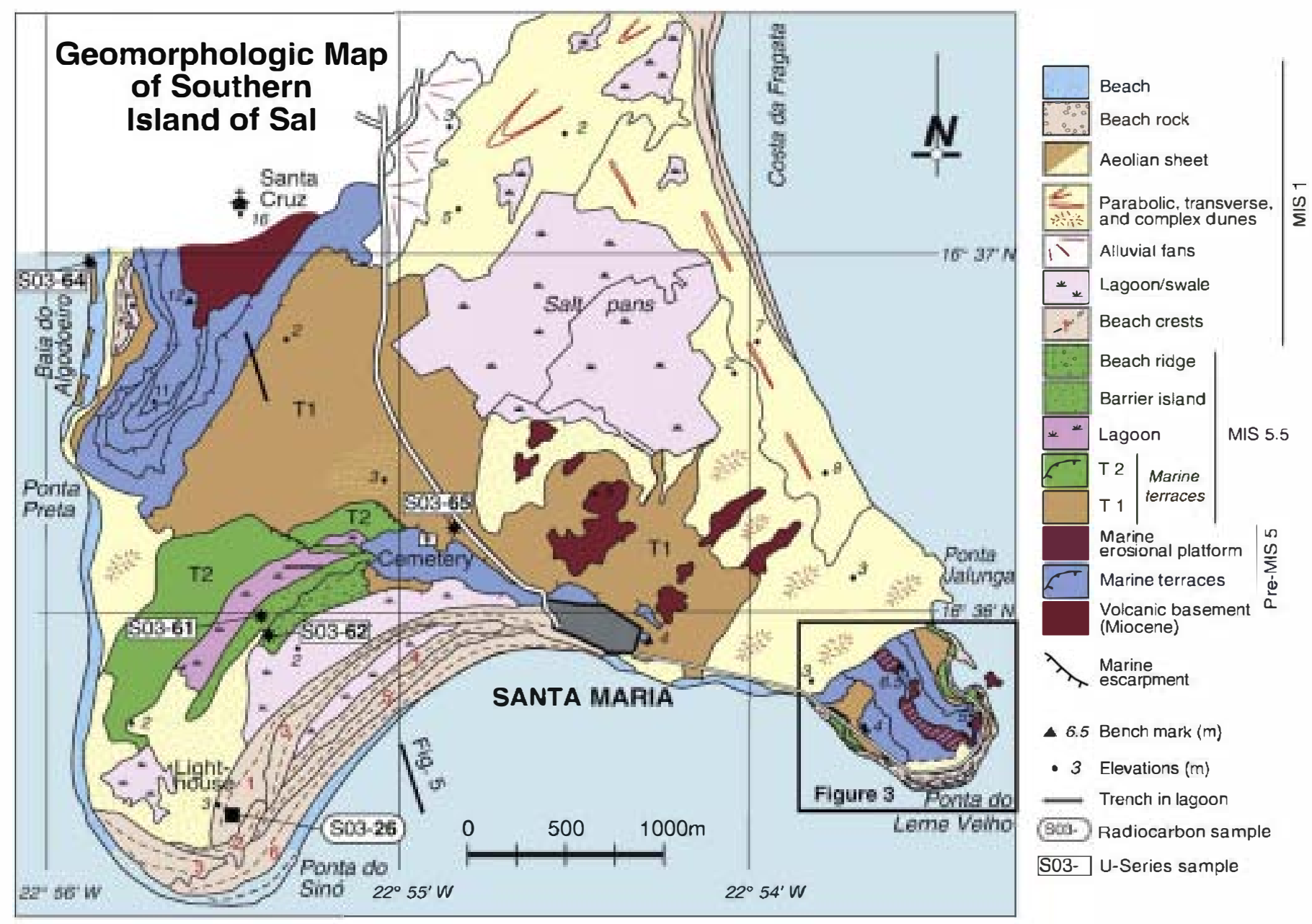

Fig. 2. Geomorphologic map of Late Pleistocene and Holocene deposits in southern Sal Island (Cape Verde) with location of samples cited in Tables. 
Table 1

U-series measurements in samples from Sal Island (modifies after Zazo et al., 2007).

\begin{tabular}{|c|c|c|c|c|c|c|c|c|c|c|c|c|c|c|c|c|}
\hline \multirow[t]{2}{*}{ Sample \# } & Sample ID marine & \multirow[t]{2}{*}{$\%$ Arag. } & \multirow[t]{2}{*}{${ }^{238} \mathrm{Uppm}$} & \multirow[t]{2}{*}{ \pm} & \multirow[t]{2}{*}{${ }^{232} \mathrm{Th} \mathrm{ppb}$} & \multirow[t]{2}{*}{ \pm} & \multirow[t]{2}{*}{${ }^{234} \mathrm{U} / /^{238} \mathrm{U}^{*}$} & \multirow[t]{2}{*}{ \pm} & \multirow[t]{2}{*}{${ }^{23 \bullet} \mathrm{Th} /{ }^{234} \mathrm{U}^{*}$} & \multirow[t]{2}{*}{ \pm} & \multirow[t]{2}{*}{${ }^{230} \mathrm{Th} /{ }^{232} \mathrm{Th}^{*}$} & \multirow[t]{2}{*}{ \pm} & \multirow{2}{*}{$\frac{\text { Calc. }}{\text { Age ky }}$} & \multirow[t]{2}{*}{$+1-$} & \multirow[t]{2}{*}{ Locality } & \multirow{2}{*}{$\frac{\text { Elev. }}{\text { masl }}$} \\
\hline & Unit & & & & & & & & & & & & & & & \\
\hline \multicolumn{17}{|c|}{$\begin{array}{l}\text { Coral and hydrozoan }{ }^{* * *} \text { samples } \\
\text { Holocene }\end{array}$} \\
\hline S03-51 & $\begin{array}{l}\text { Millepor } \mathrm{sp}^{* * * *} \\
\text { b.r. }\end{array}$ & 96.6 & 0.6709 & 0.0044 & 0.791 & 0.009 & 1.1699 & 0.0075 & 0.0025 & 0.0017 & 7.5 & 5.1 & $0.3^{* *}$ & \pm 0.2 & Ponta Ieme Velho & 0 \\
\hline S03-58 & $\begin{array}{l}\text { Millepor sp }{ }^{* * *} \\
\text { beach }\end{array}$ & 98.8 & 0.8450 & 0.0040 & 153.7 & 1.2 & 1.1516 & 0.0060 & $\ll$ & & $\ll$ & & modern & & Ponta Jalunga & 0 \\
\hline S03-64 & $\begin{array}{l}\text { Favia fragum } \\
\text { Beach }\end{array}$ & 98.7 & 2.505 & 0.015 & 2.278 & 0.016 & 1.1525 & 0.0086 & 0.0016 & 0.0001 & 6.34 & 0.46 & $0.18^{* *}$ & \pm 0.013 & P. Preta (B. Algodoeiro) & 0 \\
\hline \multicolumn{17}{|c|}{ Last Intergiacial } \\
\hline SO3-57**** & $\begin{array}{l}\text { Unidentified coral } \\
\mathrm{T} 1\end{array}$ & n.d. & 2.4739 & 0.0151 & 129.64 & 1.4092 & 1.202 & 0.0073 & 0.6627 & 0.0124 & & & 114.8 & \pm 4 & Ponta Braço Sirena & 1.8 \\
\hline S03-61 & $\begin{array}{l}\text { Millepora } \mathrm{sp}^{* * *} \\
\text { b.i. (T2) }\end{array}$ & 78.9 & 0.5720 & 0.0030 & 5.826 & 0.049 & 1.1127 & 0.0100 & 0.6990 & 0.0141 & 233.5 & 4.8 & 126.6 & $+5.1 /-4.9$ & NW Cemetery (S. Maria) & 2 \\
\hline S03-65 & $\begin{array}{l}\text { Favia fragum } \\
\mathrm{T} 1\end{array}$ & 97.8 & 2.909 & 0.018 & 0.4029 & 0.0048 & 1.1293 & 0.0100 & 0.6891 & 0.0100 & 17172 & 302 & 122.9 & $+3.6 /-3.4$ & Santa Maria Bay & 2.5 \\
\hline S03-68-1 & $\begin{array}{l}\text { Siderastrea radians } \\
\mathrm{T} 1\end{array}$ & n.d. & 2.703 & 0.015 & 1.647 & 0.011 & 1.0976 & 0.0062 & 0.6586 & 0.0047 & 3624 & 35 & 114.2 & $+1.6 /-1.5$ & South Baia Murdeira & 0 \\
\hline S03-68-2-e & $\begin{array}{l}\text { S. radians (top) } \\
\mathrm{T} 1\end{array}$ & 89.4 & 2.4197 & 0.0013 & 36.044 & 0.028 & 1.1220 & 0.0094 & 0.6972 & 0.0088 & 160.5 & 2.1 & 125.7 & $+3.2 /-3.1$ & South Baia Murdeira & 0 \\
\hline S03-68-2-d & $\begin{array}{l}\text { S. radians (interm.) } \\
\mathrm{T} 1 \mathrm{l}\end{array}$ & 98.1 & 2.7304 & 0.0018 & 3.050 & 0.029 & 1.1214 & 0.0068 & 0.7034 & 0.0074 & 2158 & 31 & 127.8 & \pm 2.7 & South Baia Murdeira & 0 \\
\hline S03-68-2-c & $\begin{array}{l}\text { S. radians (middle) } \\
\mathrm{T} 1\end{array}$ & 98.25 & 2.6648 & 0.0119 & 0.402 & 0.003 & 1.1180 & 0.0067 & 0.6971 & 0.0071 & 15798 & 190 & 125.8 & $+2.6 /-2.5$ & South Baia Murdeira & 0 \\
\hline S03-68-2-b & $\begin{array}{l}\text { S. radians (interm.) } \\
\mathrm{T} 1\end{array}$ & 100 & 2.7629 & 0.0017 & 2.762 & 0.034 & 1.1150 & 0.0067 & 0.7051 & 0.0100 & 2404 & 45 & 128.5 & $+3.7 /-3.5$ & South Baia Murdeira & 0 \\
\hline S03-68-2-a & $\begin{array}{l}\text { S. radians (bottom) } \\
\mathrm{T} 1\end{array}$ & 98.3 & 2.703 & 0.0015 & 7.633 & 0.006 & 1.1030 & 0.0011 & 0.7058 & 0.0104 & 843 & 12 & 129.2 & $+4.0 /-3.8$ & South Baia Murdeira & 0 \\
\hline S03-69 & $\begin{array}{l}\text { Siderastrea radians } \\
\mathrm{T} 1\end{array}$ & 80.4 & 2.767 & 0.016 & 40.72 & 0.36 & 1.1008 & 0.0088 & 0.6453 & 0.0080 & 147.5 & 2.1 & 110.2 & \pm 2.5 & South Baia Murdeira & 0 \\
\hline SO6-34 $4^{* * * *}$ & $\begin{array}{l}\text { Siderastrea radians } \\
\mathrm{T} 1 / \Gamma 2\end{array}$ & n.d. & 2.706 & 14.5 & 0.7088 & 0.0037 & 1.0978 & 0.0044 & & & & & 130.4 & \pm 1.4 & Baia Parda & 2 \\
\hline \multicolumn{17}{|c|}{ Pre- Last Intergiacial } \\
\hline S03-54 & $\begin{array}{l}\text { Siderastrea radians } \\
\text { m.t. }\end{array}$ & n.d. & 2.752 & 0.026 & 2.364 & 0.027 & 1.0650 & 0.0094 & 0.9671 & 0.0128 & 3663 & 65 & 322 & $+35 / 26$ & Sta. Maria - P. L. Velho & 5 \\
\hline SO3-55 & $\begin{array}{l}\text { Siderastrea radians } \\
\text { m.t. }\end{array}$ & 98.8 & 2.879 & 0.019 & 1.6104 & 0.0037 & 1.0644 & 0.0071 & 0.9770 & 0.0209 & 5681 & 177 & 343 & $+73 /-43$ & Ponta Braço Sirena & $1.25 \bullet$ \\
\hline \multicolumn{17}{|c|}{ other measurements } \\
\hline SO3-2 & $\begin{array}{l}\text { Dendropom sp } \\
\text { T2 }\end{array}$ & n.d. & 0.2337 & 0.0012 & 51.116 & 0.010 & 1.1554 & 0.0098 & 0.6671 & 0.0115 & 10.76 & 0.19 & 115.4 & $+3.7 /-3.6$ & Santa Maria Bay & 1.5 \\
\hline S03-52 & $\begin{array}{l}\text { Dendropom sp } \\
\text { Swale }\end{array}$ & 98.1 & 0.7727 & 0.0043 & 5.989 & 0.052 & 1.1623 & 0.0100 & 0.0159 & 0.0013 & 7.27 & 0.58 & $1.7^{* *}$ & \pm 0.1 & Ponta Ieme Velho & 0.25 \\
\hline S03-57 & $\begin{array}{l}\text { Rhodolith } \\
\text { T1 }\end{array}$ & n.d. & 0.6370 & 0.0060 & 195.3 & 4.0 & 1.1810 & 0.0180 & 0.4630 & 0.0120 & 5.45 & 0.17 & $66.4^{* *}$ & \pm 2.5 & Ponta Braço Sirena & 1.8 \\
\hline S03-62 & $\begin{array}{l}\text { Unid. shell fragment } \\
\text { b.r.(T2) }\end{array}$ & n.d. & 0.1605 & 0.0014 & 0.814 & 0.013 & 1.2020 & 0.0103 & 0.7314 & 0.0225 & 529 & 18 & 135.0 & $+8.5 /-7.9$ & NW Cemetery (S. Maria) & 1.5 \\
\hline
\end{tabular}

* Activity ratios; ** Ages requiring correction owing to detrital contents; ${ }^{* * *}$ Hydrozoan; **** new samples.

- Elevation measured at the sea front of the marine terrace.

Marine units: b.i. (T2), barrier island associated to T2 marine terrace; b.r.(T2), beach ridge associated to T2 marine terrace; m.t., pre-MIS 5.5 marine terrace. 
Table 2

Database of ${ }^{14} \mathrm{C}$ samples and laboratory results.

\begin{tabular}{|c|c|c|c|c|c|c|c|c|}
\hline $\begin{array}{l}\text { Sample } \\
\text { number }\end{array}$ & $\begin{array}{l}\text { Laboratory } \\
\text { number }\end{array}$ & Locality & Material & ${ }^{14} \mathrm{C}$ age $\mathrm{yr}$ & Cal. age yr $(2 \sigma)$ & $\delta^{13} \mathrm{C} \%$ & Observations & Unit \\
\hline S02-3 & GX29029 & Cascalhos & Shell & $24870 \pm 790$ & & 1.6 & Arca & T1 (Iast Interglacial) \\
\hline S02-13 & GX29810 & P. do Ieme Velho & Shell & $>41430$ & & 1.7 & Strombus latus & Holocene Beach ridge \\
\hline S03-26 & GX31006 & Sta. Maria Lighthouse & Shell & $5940 \pm 50$ & $6890-6660 \mathrm{BP}$ & -8.1 & Terrestrial gastropod Zootecus insularis & Holocene Foredune \\
\hline
\end{tabular}

of the marine terrace. The erosional surface is covered by a $0.5 \mathrm{~m}$-thick conglomerate with angular pebbles and a reddish sandy mudstone matrix deposited by low-gradient alluvial fans. The top of this muddy conglomerate is cemented and partly karstified (see detail in Fig. 5).

The marine terrace T2 covers a smaller surface (Fig. 2). The associated deposits consist of cemented fossiliferous conglomerates showing an off-lapping architecture (Fig. 5), and are interpreted as shoreface facies. The beach deposits associated with $\mathrm{T} 2$ are inserted into the deposits of the preceding terrace (T1). Locally, a low escarpment separates T1 and T2 (e.g. north of Santa Maria Cemetery, Fig. 2), but is never high enough to expose the underlying volcanic rocks.

West of the Santa Maria Cemetery, T2 is covered by whitish sandy to clayey carbonate deposits rich in rhodolites (algal balls) and Strombus latus. These deposits fill an elongated depression. They are all that remain of a swale or narrow lagoon, and have evolved into brown soil at the surface (Fig. 6a). The lagoon was originallyseparated from the sea by a barrier island oriented northeast-southwest (Figs. 2 and 5) that consists of parallel-laminated calcarenites, very much resembling a foreshore facies. The barrier was partly eroded and covered by fossiliferous conglomerates and calcarenites with an off-lapping architecture that evidences progradation to the south (Figs. 2, 5 and $6 \mathrm{~b})$. The top of the cemented calcarenites is scoured, presumably by wave action. Scours are predominantly oriented towards the sea (south/ southeast). A younger, partly cemented conglomerate that covers the scoured surface is thought to represent a newer and younger prograding beach ridge (Figs. 2, 5 and $6 \mathrm{~b}$ ).

Sedimentation in the southwestern side of Sal Island, between Santa Maria and Ponta do Sinó (Fig. 2), was reactivated in recent times when a series of beach ridges prograded towards the southwest leaving behind a lagoon (Fig. 7a) and narrow swales. These noncemented deposits form a wide coastal plain where low foredunes (Fig. 7b) cover beach ridges and extend to the modern shoreline.

In the southeastern tip of Sal Island, marine terraces are reduced to narrow platforms with associated fossiliferous, cemented conglomerates surrounding a small volcanic outcrop. The former volcanic relief has been eroded by wave action forming a low platform (Figs. 2 and 3)
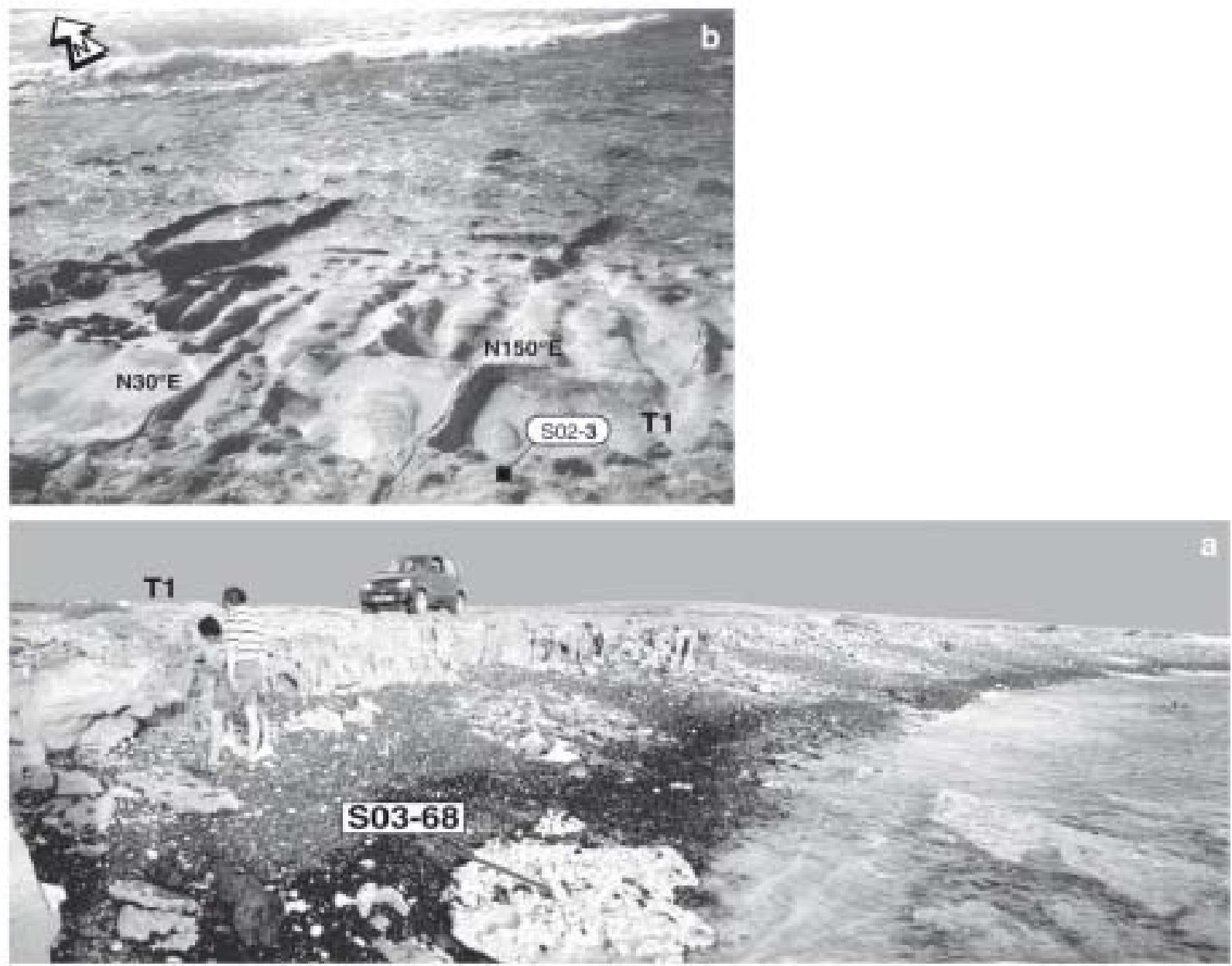

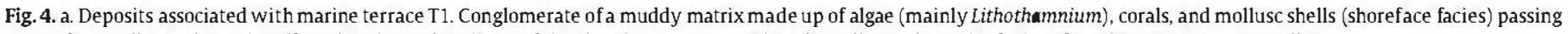
upwards to yellow calcarenites (foreshore). South Baia Murdeira; b. Joint systems cutting the yellow calcarenite facies of marine terrace T1. Cascalhos. 


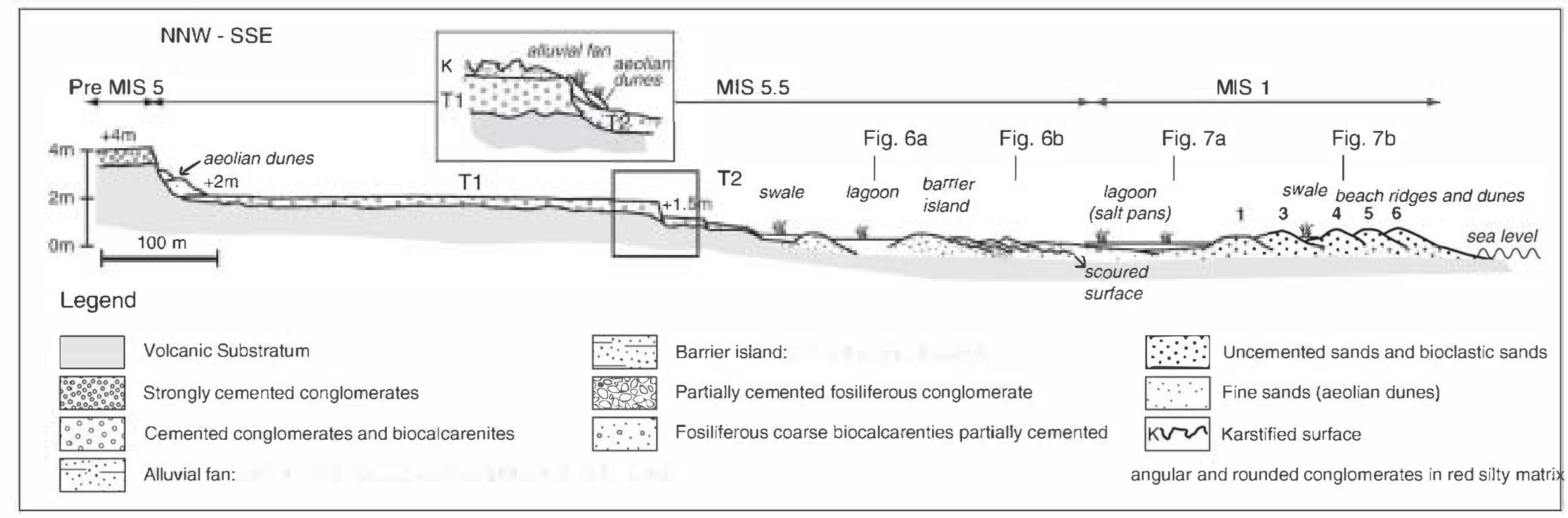

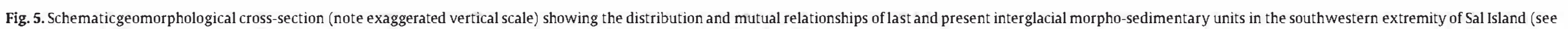
location in Fig. 2), and the location of photographs shown in Figs. 6a,b and 7a,b. 

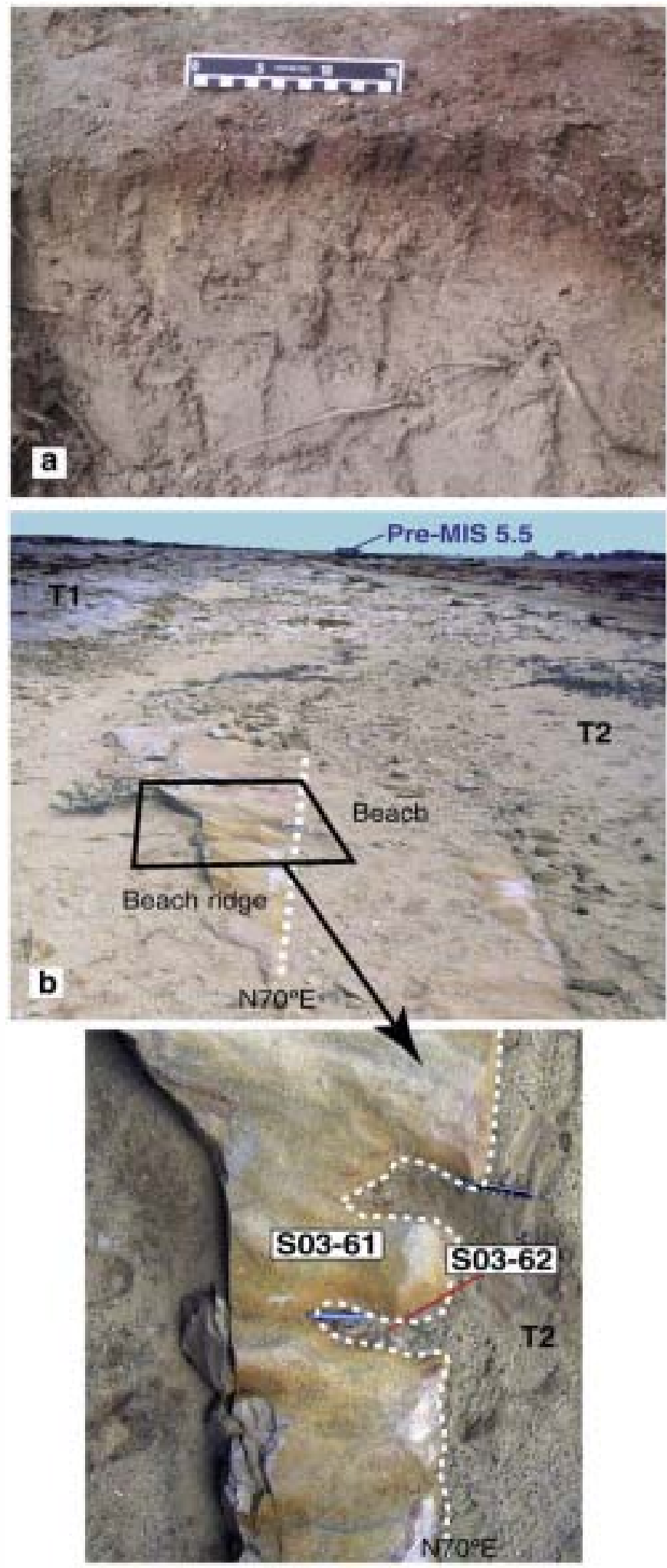

Fig. 6. a. Lagoonal white silty sands, rich in algae rhodoliths and Strombus latus, and in situ developed brown soil. The total thickness exposed in the trench is $\sim 1.2 \mathrm{~m}$. West of Santa Maria Cemetery, see Fig. 2 for location; b. Fluctuations of sea level within second major oscillation inside MIS 5.5. Beach progradation towards the SE (to the right of observer) marked by a gentle inclination of bedding, separated by erosion. Both units dip gently to the SE. Cemented fossiliferous calcarenites with top scoured by wave erosion. Close-up of the overlying partly-cemented fine-grained conglomerate fills the scours (see also Fig. 5). Note ruler $(15 \mathrm{~cm}$ ) and blue ball pencil for reference in the two photographs.
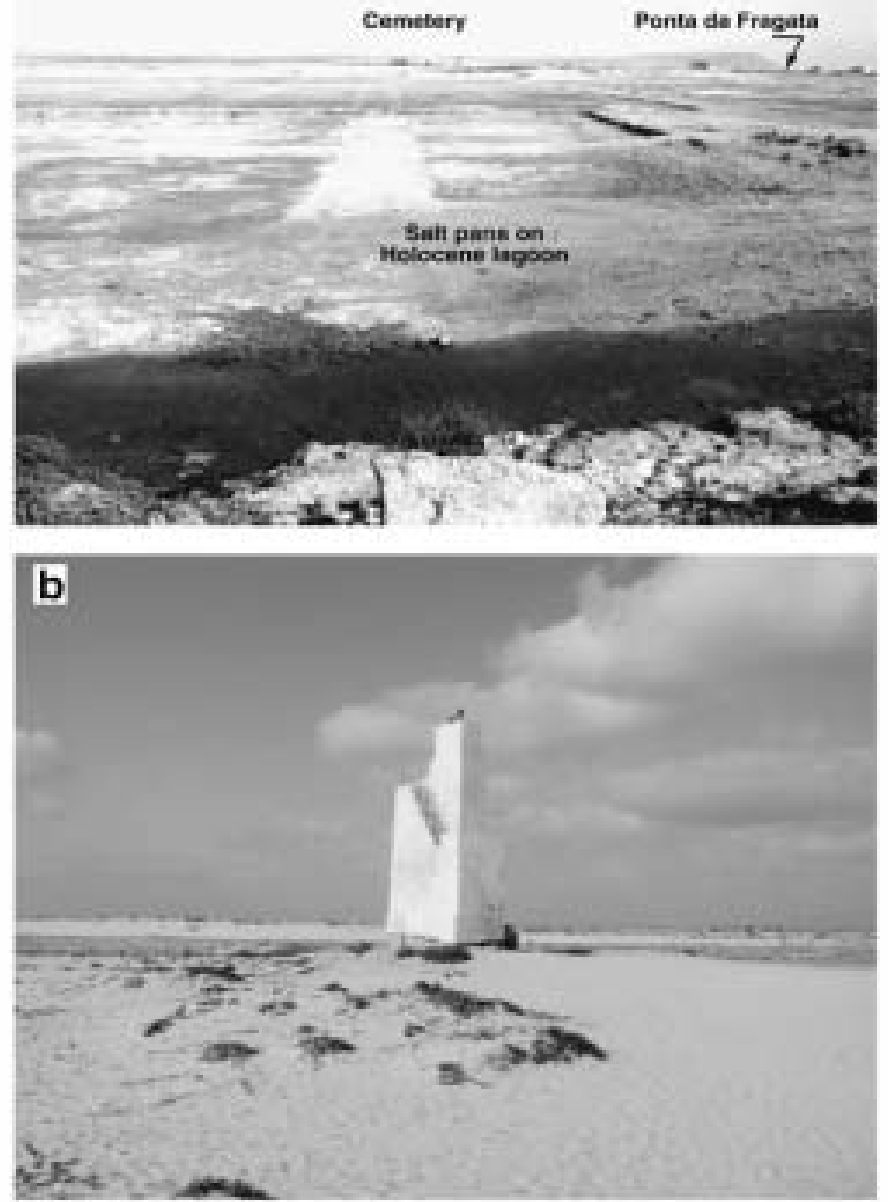

Fig. 7. a. The abandoned salt pans of Santa Maria, built on the depression of a former Holocene lagoon. The photograph was taken looking towards the north; b. Beach ridges and swales partly covered by foredunes. The photograph was taken looking to the northwest. lighthouse is around $8 \mathrm{~m}$ high.

where the degraded remains of a beach ridge can still be recognized (Fig. 8a, b). The best preserved sequence of marine terraces is exposed around the southwestern margin, where the aeolian cover is thinner, thus allowing the observation of small coastal palaeocliffs. At the foot of these paleocliffs, accumulations of boulders that changes laterally into sandier coastal deposits mark the inner edge of the marine terrace (Fig. 8). In this area, T1 and T2 consist largely of fossiliferous conglomerates less that $0.5 \mathrm{~m}$ thick. The inner edge of the older terrace (T1) rises up to +1.5 masl. Terrace T2 is incised $0.3 \mathrm{~m}$ into the former unit (T1), with a rudimentary beach ridge marking the position of the corresponding coastline. A further marine terrace, at +3 masl, is difficult to interpret: we tentatively assign it a pre-T1 age.

Younger, non-cemented beach ridges separated by swales (Figs. 3 , $8 \mathrm{a}$ and $9 \mathrm{a}, \mathrm{b})$ surround the formerly described units. Beach ridges rise up to $3 \mathrm{~m}$ due to the very coarse grain size (coarse pebble to boulder, Fig. 9a). Huge amounts of Strombus shells and of algae rhodolites (Fig. 10) accumulated in a little bay that is limited by volcanic and beach rock headlands, north of Ponta Braço de Sirena (Fig. 3).

Deposits laterally equivalent to $\mathrm{T} 1$ and $\mathrm{T} 2$ are represented in the southwestern part of Sal Island (Figs. 1 and 2) as a narrow fringe bordering the moderately exposed bays of Algodoeiro and Murdeira, reaching maximum elevations about +2 masl. 

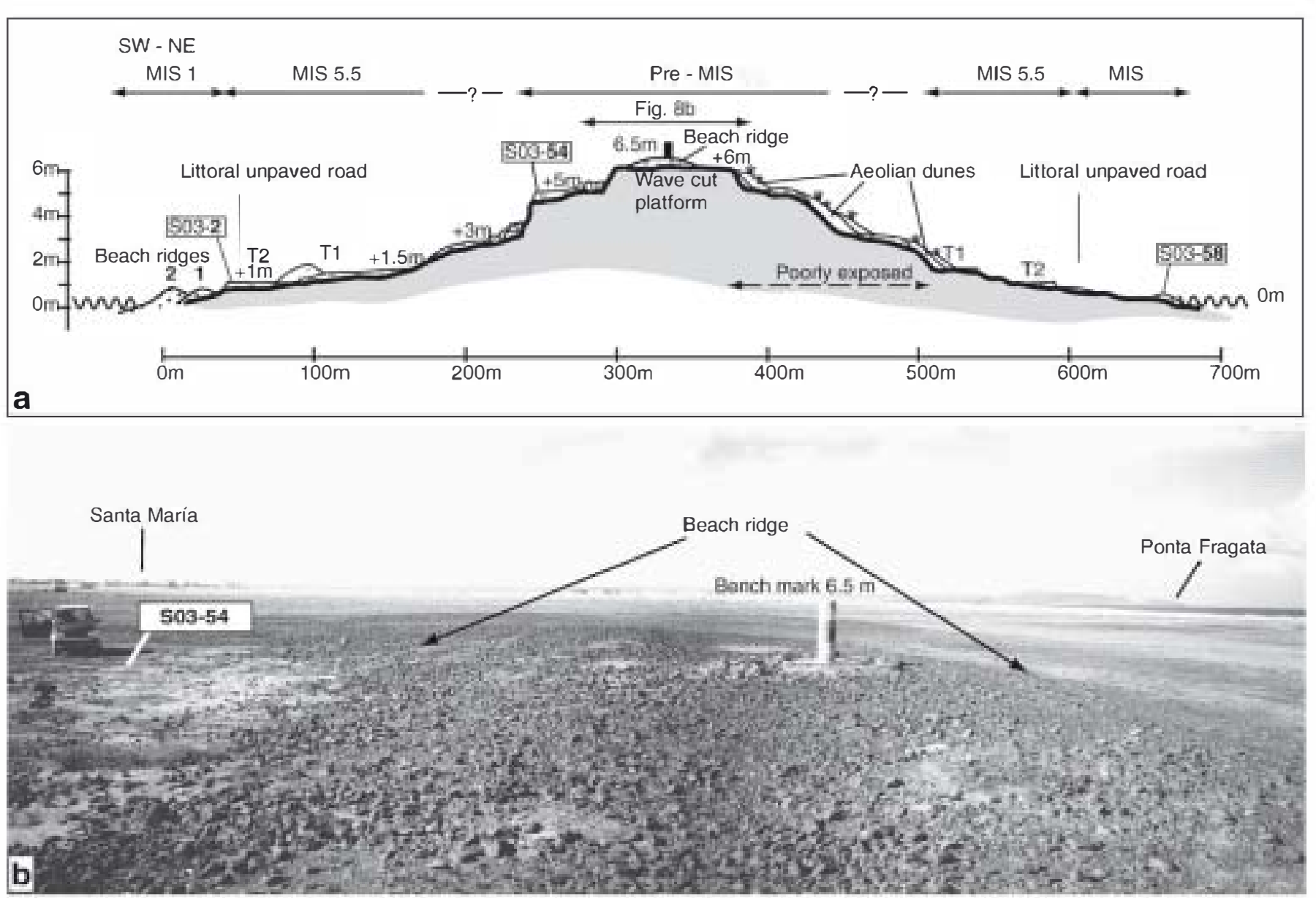

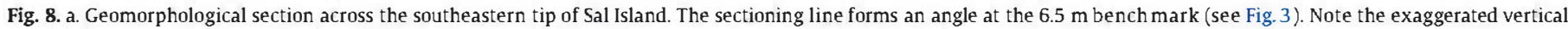
scale; b. Panorama looking north of pre-MIS 5.5 terraces at the $6.5 \mathrm{~m}$ bench mark See text for explanation.

\subsection{Paleontological studies}

Lecointre $(1962,1963,1965)$ recognized three marine terraces with Strombus bubonius in Sal Island between +55 masl and $\sim 0 \mathrm{~m}$. The oldest terrace was probably affected by tectonics. This author stated the chronology of terraces based on their relative topographic elevations, which he compared with those in the Moroccan and Mediterranean coasts: 50-13 m, Anfatian (PalaeotyrrhenianEutyrrhenian); 8-7 m, Ouljian (Neotyrrhenian); and 1-0 m, Mellahian (Flandrian).

Later, García-Talavera $(1987,1999)$ studied the area from Baia Murdeira to Ponta do Leme Velho and noted the close similarities of the present and fossil faunas collected from deposits between 0 and +5 masl. He also cited the occurrence of the molluscs Strombus latus, Cantharus viverratus and Conus ermineus.

Our paleontological studies on Pleistocene marine terraces and Holocene beach ridges in the southern Sal Island, although still preliminary, indicate a widespread occurrence of S. Iatus Gmelin (syn: $S$. bubonius Iamarck) with other tropical species, particularly from the $+38 \mathrm{~m}$ terrace (Early Pleistocene, Zazo et al., 2004) onwards. A few of these species are also found in last interglacial deposits of the Mediterranean realm and are referred to as the warm "Senegalese" fauna (Gignoux, 1913; Issel, 1914; Cuerda, 1989): Strombus bubonius Lamarck, Cardita senegalensis (Reeve), Conus testudinarius Martini (syn.: Conus ermineus Born), Cantharus viverratus (Kiener) (syn.: Cantharus variegatus Gray), and Polynices lacteus (Guilding).

A few species of Scleractinian corals (Siderastrea radians (Pallas) and Favia fragum (Esper) and calcareous Hydrozoan (Millepora) are abundant in the described marine terrace deposits, but only $S$. radians has potential constructional capability. The Melobesoideae calcareous algae (Lithothamnium, Lithophyllum, Melobesia) are very abundant.

Studies on shallow epibenthic communities of Sal Island based on several transects perpendicular to the shorelines down to $-33 \mathrm{mbsl}$ (below sea level) reveal that $S$. latus ( $S$. bubonius) lives in water between 4 and 9 m deep in moderately exposed coasts of Santa Maria Bay with sandy to gravelly bottoms (Morri et al., 2000). Siderastrea radians, Favia fragum and Millepora are abundant in sheltered areas with a water depth of less than $1 \mathrm{~m}$. We have observed similar paleoecological conditions during the last interglacial: $S$. bubonius is found in sheltered areas, particularly in the barrier island-lagoon systems of Sal Island, Eastern Canary Islands (Zazo et al, 2002, 2003), the Spanish Mediterranean coasts (Goy et al, 1993) and Balearic Islands (Cuerda, 1989). So far, we have not found this species in the rocky and exposed coasts of Sal Island.

\subsection{U-series data}

Data on Scleractinian corals and calcareous Hydrozoan (Hydrocorallina) samples from southern Sal Island fall broadly into three sets of values (see Table 1). Samples collected from unconsolidated deposits yielded values corresponding to a very late Holocene age.

A last interglacial group (MIS 5.5) shows some outliers corresponding to corals or calcareous Hydrozoan with $20 \%$ or more calcite contents. However, in most samples, a rather homogeneous $\mathrm{U}$ content with narrow ${ }^{234} \mathrm{U} /{ }^{238} \mathrm{U}$ activity ratios still preserved a nearmarine original signature. Two samples collected from marine terraces suggest pre-last interglacial ages: Sample S03-55 was collected from the sea-front of a terrace which is overlain by the 

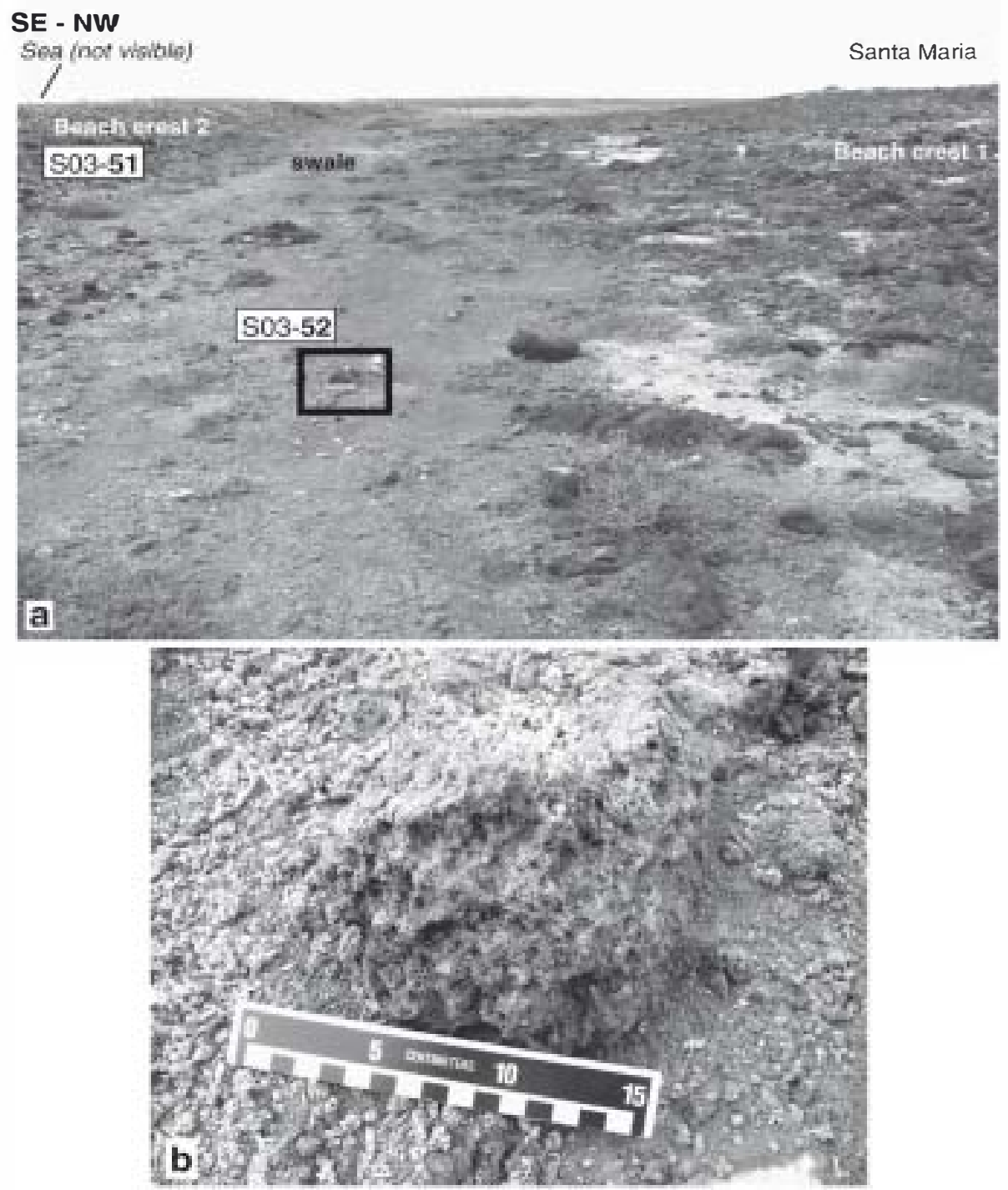

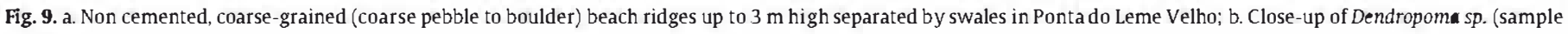
S03-52).

MIS 5.5 terrace between Ponta do Leme Velho and Braço Sirena; Sample S03-54 was also collected in the southeastern part of the island, but inland (Fig. 3). The ${ }^{230} \mathrm{Th}$ ages $(\sim 330 \mathrm{ka})$ would be compatible with a tentative MIS 9 assignment.

A few comparative measurements were performed on mollusc shells from deposits thought to be of the last interglacial age. These were based on field and geochemical evidence, as a means to constrain the isotopic signature of any diagenetic uranium (e.g. Kaufman et al, 1996). They depict ${ }^{234} \mathrm{U} /{ }^{238} \mathrm{U}$ activity ratios in the 1.15 to 1.2 range, thus accounting for the relatively low excess in ${ }^{234} \mathrm{U}$ shown by partly recrystallized corals. It is worthwhile to mention that the largest time offset of these outliers is shown by a Millepora (calcareous Hydrozoan) fossil. This fossil has much lower initial Ucontents than Scleractinian corals, as illustrated by $U$ contents in Millepora (with approximately 0.7 to $0.8 \mathrm{ppm}$ of U, vs. $2.7 \mathrm{ppm}$ in the Scleractinian coral Siderastrea radians).

Otherwise, most last interglacial corals are relatively well clustered but nonetheless depict a slight trend above the theoretical ${ }^{234} U /{ }^{238} U$ value expected for "marine uranium" in this range of age. Several processes may account for such a trend (e.g., Thompson et al, 2004), but their impact on the calculated ages seems of minor importance in our case. This is illustrated by seriate measurements (Table 1) in one $S$. radians sample showing three growth phases, the last two of which are separated by a stage of intense bio-erosion. In this sequence, despite the fact that the outlying part of the coral shows a relatively high calcite content (about 10\%), all ages are concordant within their $2 \sigma$-standard deviation.

\subsection{Radiocarbon data}

The few radiocarbon ages (Table 2) of selected samples from marine deposits located at very low altitudes (S02-3 in Figs. 1 and 4b; S03-26 in Fig. 2; S02-13 in Fig. 3) are at the method age-limit or beyond it.

Sample S02-3 $\left({ }^{14} \mathrm{C}\right.$ age of $24,870 \pm 790 \mathrm{yr}$. BP) comes from cemented yellow calcarenites at the top of marine terrace $\mathrm{T} 1$; it was taken in the same marine unit than samples S03-68 and S03-69 (Figs. 1, 4a, b, and Table 1). Sample S02-13 ( ${ }^{14} \mathrm{C}$ age of $41,430 \mathrm{yr}$. BP) was collected from the same uncemented beach crest and swale system as S03-51 and S03-52 (see Figs. 3, 9a, b, and Table 1). From the stratigraphy and U-series data we deduce a last interglacial age for S02-3 and a Holocene age for S02-13. 


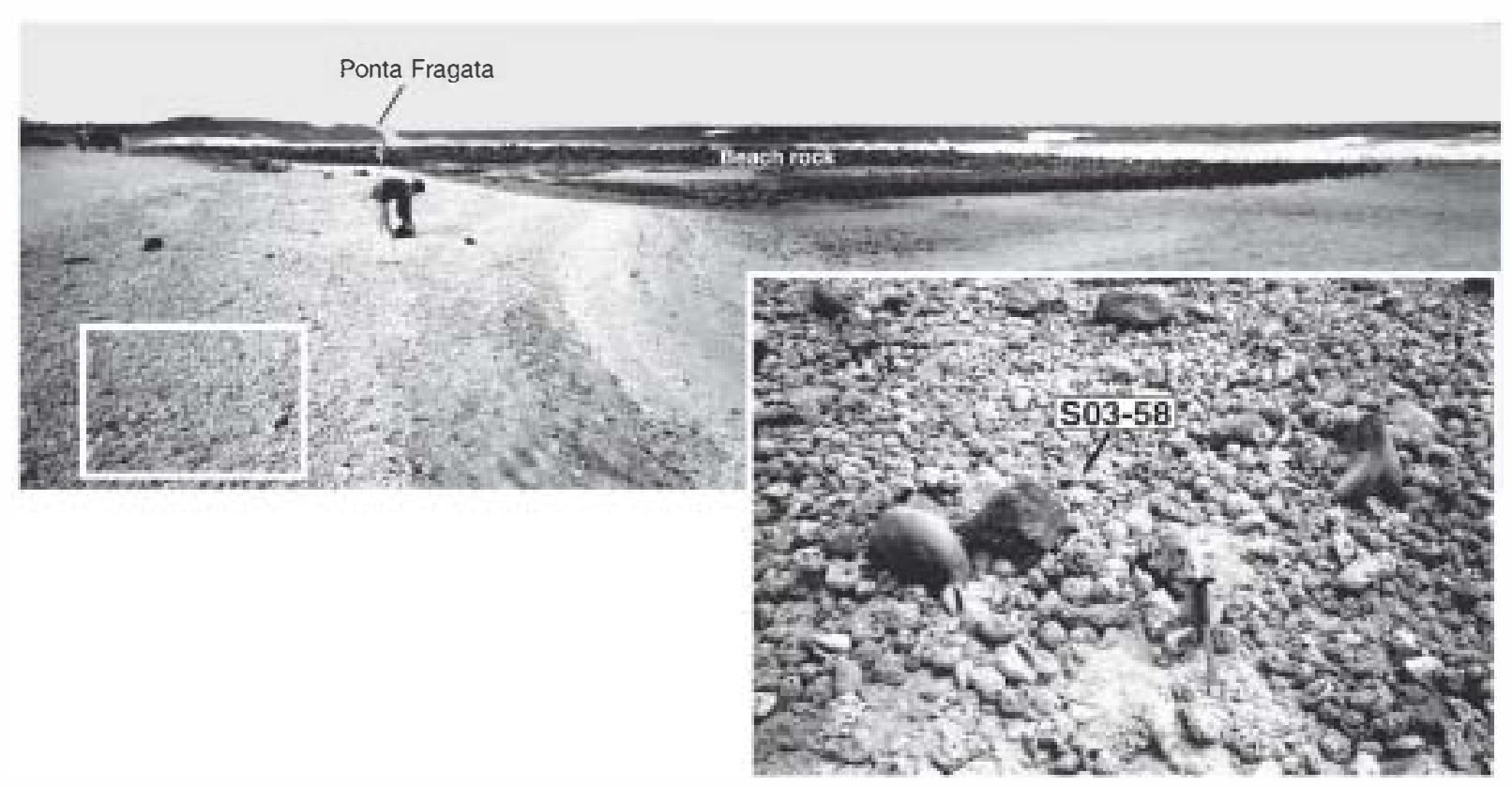

Fig. 10. Accumulation of Strombus shells and algae rhodolites in a little bay north of Ponta Braço de Sirena.

One sample (S03-26, Fig. 2) was collected from a foredune overlying the oldest modern beach ridges in Ponta do Sinó.

\subsection{Field data and chronological framework}

Field data and ${ }^{230} \mathrm{Th}$ ages suggest that the last interglacial deposits (MIS 5) occurred at elevations below +2.5 masl. Most data (Table 1) were obtained from terrace T1, with ages ranging from $110 \mathrm{ka}$ and $130 \mathrm{ka}$, largely corresponding to MIS 5. In relation to terrace T2 and the barrier island deposits, they must be of MIS 5, but U-Th and radiocarbon measurements were not accurate enough to discriminate which substage they belong to. The terrace preceding $\mathrm{T} 2$, and topographically higher ( $+3-4$ masl), may represent a highstand inside MIS 7, taking into account that it is incised into a terrace, at elevation $+5-6$ masl (Fig. 8a), that was dated with ${ }^{230}$ Th as $\sim 330 \mathrm{ka}$.

\subsubsection{Sea level changes during the last interglacial: other regions}

Despite the many papers devoted to the duration, number of highstands, and paleo-sealevel elevations during the last interglacial, there is great controversy concerning these issues even in areas considered tectonically stable where raised coral terraces provide good material for U-series dating.

4.5.1.1. MIS 5.5. The number of highstands inside this substage is under discussion. In the tectonically stable, tropical Atlantic regions such as the Bahamas (Chen et al, 1991; Muhs, 2002; Mylroie, 2007) and Bermuda (Muhs, 2002), a prolonged highstand ( 130 to $120 \mathrm{ka})$ with sea level $\sim 5$ masl is usually suggested. In contrast, Neumann and Hearty (1996) suggested two highstands in the Bahamas between 132-118 ka, with sea level around $\sim 2$ masl during most of the time interval, and a rapid and brief rise of sea level up to +6 masl just before the end of the substage. In Bermuda, Hearty (2002) also found two highstands during MIS 5.5, the older (132-125 ka) with sea level at $\sim+2.5$ masl, and the younger $(120-115 \mathrm{ka})$ with sea level at $+6 \mathrm{~m}$ or +9 masl. These two highstands are separated by a mid regression $(\sim 125 \mathrm{ka})$ when sea level fell $\sim-3 \mathrm{~m}$ b.s.l.

In the tectonically active coasts of Haiti, two highstands have been recognized: the older $(130.5 \mathrm{ka})$ with a paleo-sealevel at +5 masl, and the younger $(\sim 118 \mathrm{ka})$ with a paleo-sealevel at +2.7 masl
(Dumas et aL, 2006). In Barbados, Schellmann and Radtke (2004), and Schellmann et al. (2004) suggested two last interglacial sea level maxima aged $\sim 132 \mathrm{ka}$ (ESR) or $\sim 128 \mathrm{ka}$ (U/Th), and $\sim 128 \mathrm{ka}$ (ESR) respectively, with estimated sea levels at $\sim 2 \pm 2$ masl for the older, and near the present level for the younger. Iater, $(\sim 120-118 \mathrm{ka})$ the sea level dropped to $-11 \pm 2 \mathrm{mbsl}$.

Outside the Atlantic region, the information gathered from areas of Western Australia, considered tectonically stable and located far from the former ice sheets (Stirling et al, 1998), suggested a sea level highstand at $\geq 3$ masl between $\sim 128$ and $\sim 116 \mathrm{ka}$. However, the major episode or reef building occurred between $\sim 128$ and $121 \mathrm{ka}$. Along the Northern coast of the Red Sea, Plaziat et aL (1998) described two coral terraces at +8 masl and +5 masl that correspond to two highstands developed between 125 and $115 \mathrm{ka}$.

The absence or scarcity of fossil corals in many coastal regions made it necessary to use U-series measurements, amino-acid racemization, and other dating techniques mainly on mollusc shells recovered from marine terraces, with very limited assistance from corals. This is the case in Palma Bay (Mallorca, Balearic Islands) where Hearty (1987) dated last interglacial deposits by means of amino-acid racemization and $\mathrm{U}-\mathrm{Th}$ measurements on the coral Cladocora caespitosa. Hillaire-Marcel et al. (1996) used U-series measurements on mollusc shells from the same coast to date superposed (vertically stacked) units. They obtained two groups of ages: $135 \mathrm{ka}$ for the older unit and $117 \mathrm{ka}$ for the two more recent units. Stratigraphical data suggested at least two highstands during MIS 5.5.

The number and elevation of Quaternary marine terraces in Canary Islands and Sal Island are very similar (Zazo et al., 2004, 2007). In eastern Canary Islands Zazo et aL $(2002,2003)$ recognized two morpho-stratigraphic units at elevations +2 masl and +1 masl in decreasing age order, separated by erosional features or terrestrial deposits indicative of a fall in sea level. A MIS 5.5 age has been deduced for these terraces using $U$-series measurements $\left({ }^{230} \mathrm{Th}\right.$ age about $125 \mathrm{ka}$ ) and amino-acid racemization.

Concerning the African coasts of Senegal and Mauritania, there is very little knowledge, with sparse information and a striking lack of maps and dating measurements. The situation is different for the coasts of Morocco. Between Agadir and Cap Rhir, Weisrock et al. (1999) carried out U-Th and U-Pa measurements on mollusc shells 
collected from the Ouljian terrace ( 0 to +8 masl), considered of MIS 5.5 age. Although the measured ages were often contradictory with the conclusions derived from mapping and stratigraphy, these authors suggested that the last interglacial included two stillstands. In the classical Casablanca area, Occhietti et al (2002) used amino-acid racemization on shells to recognize three amino groups corresponding to three marine terraces at elevations 0 to 6 masl, the infrequent terrace at 8 masl, and the terrace at 9 to 12 masl, which these authors assigned to MIS 5, MIS 7 and MIS 9, respectively.

4.5.1.2. MIS 5.3 and MIS 5.1. Coral ages measured in the majority of coasts, both stable and tectonically active, suggest a lower sea level during MIS $5.3(\sim 105 \mathrm{ka})$ than the present (Hearty and Kaufman, 2000; Hearty, 2002; Stirling et al, 1998; Schellmann and Radtke, 2004; Schellmann et al, 2004).

Concerning MIS 5.1 ( $~ 80 \mathrm{ka})$, a relative highstand close or slightly above present sea level has been identified by Hearty and Kaufman (2000), Muhs (2002), and Hearty (2002) in the Bahamas and in the US Atlantic Coastal Plain (Wehmiller et al, 2004). In the tectonically active coasts of Barbados, Schellmann and Radtke (2004), and Schellmann et al. (2004) suggested a sea level about -20 mbsl during MIS 5.1. In Haiti, Dumas et al. (2006) proposed a sea level at -10 mbsl for MIS 5.1 .

The relative elevations of sea level after correcting the effects of glacio-isostasy (Stirling et al, 1998) point to eustatic sea level values of up to $-10 \mathrm{~m}$ b.s.l. at $105 \mathrm{ka}$ and $\sim 80 \mathrm{ka}$. Therefore, reefs of this age can outcrop only above present sea level in areas undergoing uplift, such as Barbados and Haiti

4.5.2. Sea level changes and coastal evolution in Sal Island since $\sim 130 \mathrm{ka}$

According to the preceding considerations, the southern part of Sal Island can be considered tectonically stable or slightly subsiding at least since the last interglacial. On the other hand, the island lays geographically far away from the former ice sheets, a situation that seems to rule out any influence of the glacio-isostatic effects on the elevation of the paleo-coastlines. Therefore, we think much more feasible to assign terraces $\mathrm{T} 1, \mathrm{~T} 2$ and the associated complex of barrier island and lagoon to substage MIS 5.5, instead of the successive substages (e.g. MIS 5.5, MIS 5.3, MIS 5.1) of the last interglacial.

The paleogeographical history of the southern part of the island has been interpreted and presented as a series of sketches sequenced with roman numerals (I to VIII) in Fig. 11.

By the beginning of MIS 5, a few flattened relieves of volcanic rocks and older marine terraces barely emerged in some of the southern parts of Sal Island (Fig. 11 I). During the transgressive maximum of MIS 5.5 (Fig. $11 \mathrm{II}$ ), a thin veneer of fossiliferous calcarenites with a poorly-sorted, angular basal conglomerate formed terrace T1 around the emergent relieves. However, modern aeolian units cover the area connecting the southeastern and southwestern extremities of the island and the precise relations remain obscure.

Following a fall in sea level, a new rise led to the erosion of an arching segment out of the eastern $\mathrm{T} 1$, carving a low escarpment or micro-cliff with its toe at +1.5 masl. Then, prograding beaches (T2) grew off the emergent, topographically higher T1 (Fig. 11 II).

A new positive oscillation promoted erosion of the cemented deposits of $\mathrm{T} 2$. The coastline receded deeply to the northwest (Fig. 11 Ill). The limit of the innermost penetration is marked by a low marine escarpment (Fig. 5). Then, a prograding beach of coarse sand to gravel accumulated and eventually filled the shallow coastal embayment.

A little spit grew attached to the eastern extremity of the concave coastal segment under local littoral drift to the northwest, sheltering a tiny lagoon, still recognizable near Santa Maria Cemetery (Fig. 11 III).

A new beach barrier developed leaving behind a sheltered swale (or lagoon) (Fig. 11 IV). We interpret this as the result of renewed sedimentation with a sea level similar to that of the previous episode after a period of reduced sediment supply, in addition to a relatively low sea level that produced very low beach ridges (which were later occupied by the swale). This pattern is attributed to littoral drift towards the west/southwest.

Still smaller fluctuations of sea level promoted the erosion of the early-cemented phase-IV beach barrier units (Fig. $11 \mathrm{~V}$ ) prior to deposition of new beach units that welded to the barrier. These beaches display a conspicuous bimodal distribution of grain sizes: coarser and cemented to the east, and finer (sand-size) and virtually loose towards the southwest.

Sediment supply on the western side of the island was more reduced and depended mostly on aeolian processes, thus producing narrower, less developed coastal units (Fig. $11 \mathrm{~V}$ ).

In Sal Island, mapping, stratigraphic architecture and sedimentological data strongly suggest that the sea level repeatedly moved up and down during the peak of the last interglacial (MIS 5.5). We distinguished at least two major morpho-sedimentary units: an older terrace $\mathrm{T} 1$ and a younger ensemble made up of terrace T2 and the system of beach barrier/lagoon. The two units are separated by an erosional surface indicative of a fall in sea level, and are consequently interpreted as two separate highstands: the older with sea level elevation at $\sim+2$ masl, and the younger with sea level elevation at +1.5 masl. The relative surface areas occupied by these sedimentary units, which rest upon the same volcanic substratum (Figs. 2 and 3), suggest that sea level was more stable during the older highstand. The oscillating sea level and the changing sediment supply during the younger highstand are presumably related with rapid climatic variations at the end of MIS 5.5.

Features similar to these have been described at other locations all around the world.

Two highstands separated by an intervening period of lower sea level have been cited in the Canary Islands during the last interglacial by Zazo et al. $(2002,2003,2004)$. Facies analyses suggest a moister climate at the beginning of the substage, as indicated by fan delta sedimentation. Close to the end of the substage, numerous sea level changes promoted repeated, rapid and lateral changes of marine-terrestrial facies.

Similar climatic instability and sea level changes towards the end of MIS 5.5 have been suggested in very distinct geodynamic realms such as Western Australia, the Caribbean and Mediterranean (e.g.: Stirling et al., 1998; Neumann and Hearty, 1996; Zazo et al., 2003).

New non-cemented sandy units welded to the southwestern extremity of the island during the present interglacial. As the width of these units increases to thewest, we deduce a west-directed littoral drift.

A process comparable to that described for stage IV produced a new beach barrier-swale/lagoon system (Fig. $11 \mathrm{VI}$ ). The greater extent of sand in the south of the island sheltered the southwestern tip, allowing the accretion of beach crests just west of the Ponta do Sinó. Incipient aeolian foredunes are preserved on top of the ridges.

A repetitive pattern of reduced and increased sediment supply, with an oscillating sea level, triggered the generation of new beach barriers-swale/lagoon systems (Fig. 11 VII).

The present situation (Fig. 11 VIII) shows an intermediate pattern, probably the one active pattern during sedimentation of the previously-described units. Later erosion resulted in an apparent disconnection of both sides of the Ponta do Sinó area.

In contrast to this delicate array of units, sedimentation at the southeastern tip of the island (Ponta do Leme Velho), largely facing the trade winds, took place under a much higher wave energy and successive coarse-grained (block to boulder sized) beach crest prograded around the topographically-low headland. The coarse grain size is also responsible for the high elevation and the steep slopes of these beach crests.

${ }^{230} \mathrm{Th}$ ages of emergent Holocene marine deposits in Sal Island correspond to the very late Holocene, contrary to the Canary Islands, where emergent Holocene marine deposits are found (Zazo et al., 2002) since $\sim 4000$ yr B.P. $\left({ }^{230} \mathrm{Th}\right.$ age $)$ and $~ 5500 \mathrm{cal}$. yr B.P $\left({ }^{14} \mathrm{C}\right.$ age $)$. 

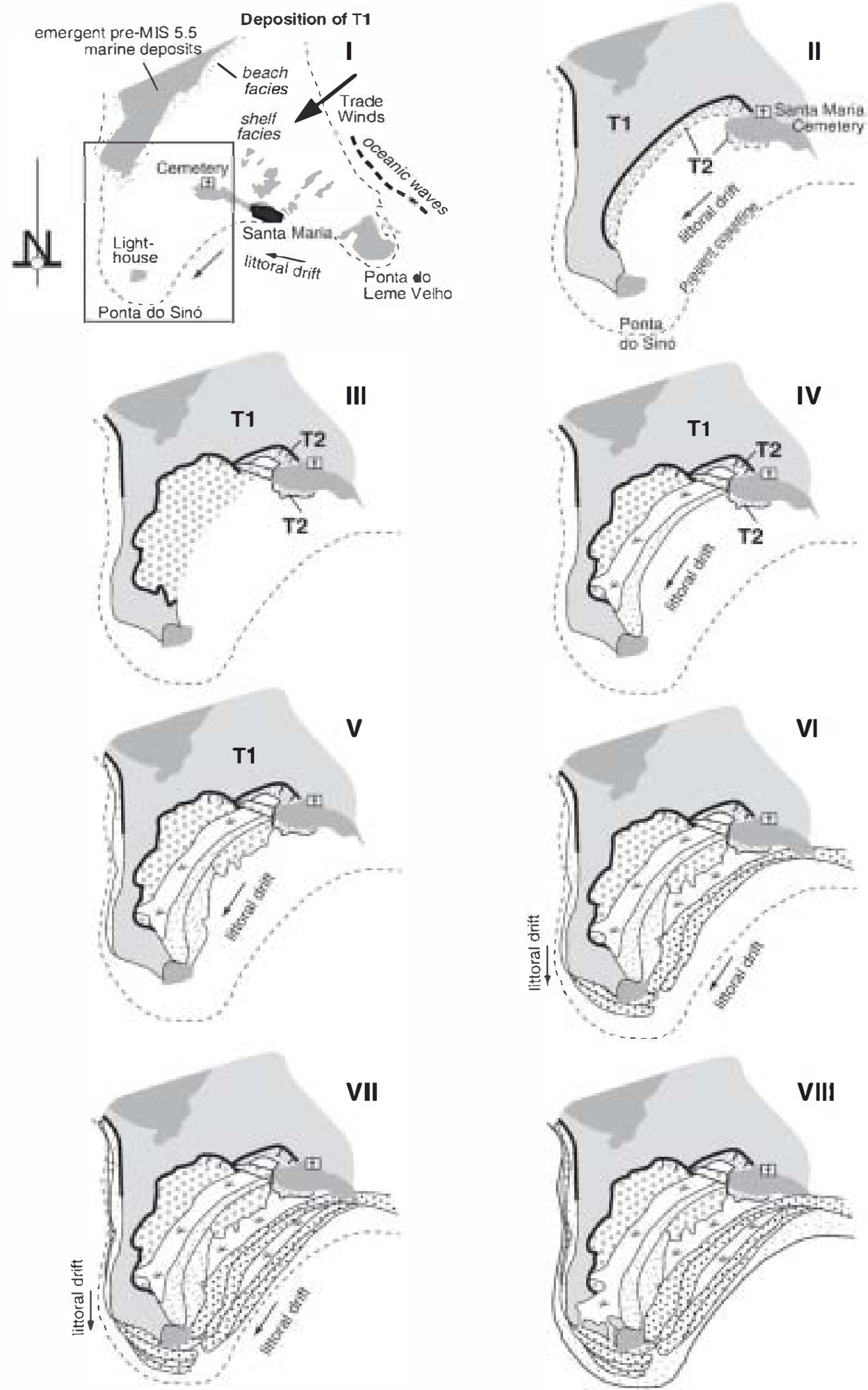

Fig. 11. Paleogeographical evolution of southern Sal Island since the last interglacial. (I) During MIS 5.5 , a few isolated low relieves barely emerged above the shallow shelf where the coarse-grained, calcarenitic to calciruditic T1 accumulated. (II-V) Successive phases of coastal erosion, and beach or barrier island progradation related to small-scale sea level oscillations that generated the complex marine terrace T2. (VI to VIII) Progradation of sandy beach crests, sometimes associated to swales or lagoons during the Holocene.

This fact could be due to the scarce dating or to a different response to hydroisostatic effect or to a combination of both. The mollusc fauna content during the last interglacial and the Holocene are similar in Sal
Island (Garcia-Talavera, 1987, 1999), contrary to the Canary Islands where the warm water species ("Senegalese" fauna) that flourished during the last interglacial are absent in the Holocene. 
46. Some remarks on mollusc faunal migrations

By comparing the relative distribution over time, mollusc faunas, and particularly some species discussed further on, can be used as ecological markers of changes in surface water temperatures.

Fig. 12 schematically illustrates the present oceanic circulation. It consists of an array of warm and cold currents that combine into the North-Atlantic Subtropical gyre and account for the distribution of fossil and present mollusc faunas. The variable amplitude and strength of the gyre in different periods have exerted a strong influence upon the geographical distribution of faunas. This is also the case of the warm "Senegalese" fauna (Strombus bubonius, Cardita senegalensis, Conus testudinarius, Cantharus viverratus and Polynices lacteus) described by Gignoux (1913), Issel (1914), and Cuerda (1989), that lived profusely on the Mediterranean coasts during the last interglacial. As the geographical distribution of Strombus is the smallest of the whole assemblage, it is common to distinguish within the "Senegalese" fauna a "fauna with Strombus" and an "accompanying fauna" void of this species. Both cases have been marked with symbols in Fig. 12. The western Mediterranean, where all warm species have been found in the last interglacial deposits, and the Atlantic-Mediterranean transition area in southern Spain illustrate the pathway of the faunal migrations into the Mediterranean.

Focusing on the islands of the Macaronesian biogeographical region, Strombus latus (syn: $S$. bubonius and the other species of the "Senegalese" warm water fauna have been found in late Pleistocene deposits of the Canary Islands (Meco et al., 1997, 2002; Zazo et al. 2002, 2005). In the Azores Islands, stratigraphical and sedimentological criteria suggest the existence of marine deposits bearing the warm tropical "Senegalese" fauna of last interglacial age between 4 and 6 masl (García-Talavera, 1987; Avila, 2000; Avila et al., 2002, 2008; Callapez and Ferreira Soares, 2000). In contrast, the warm faunas are absent in the Salvagens Islands (Garcia-Talavera and Sánchez-Pinto, 2002).

Along the western Moroccan coasts, several authors (e.g. Brebion and Ortlieb, 1976; Alouane, 2001) cited the presence of tropical fauna during the last interglacial. Weisrock et al (1999) recognized an "Ouljien" (MIS 5) marine terrace between 0 and +8 masl using

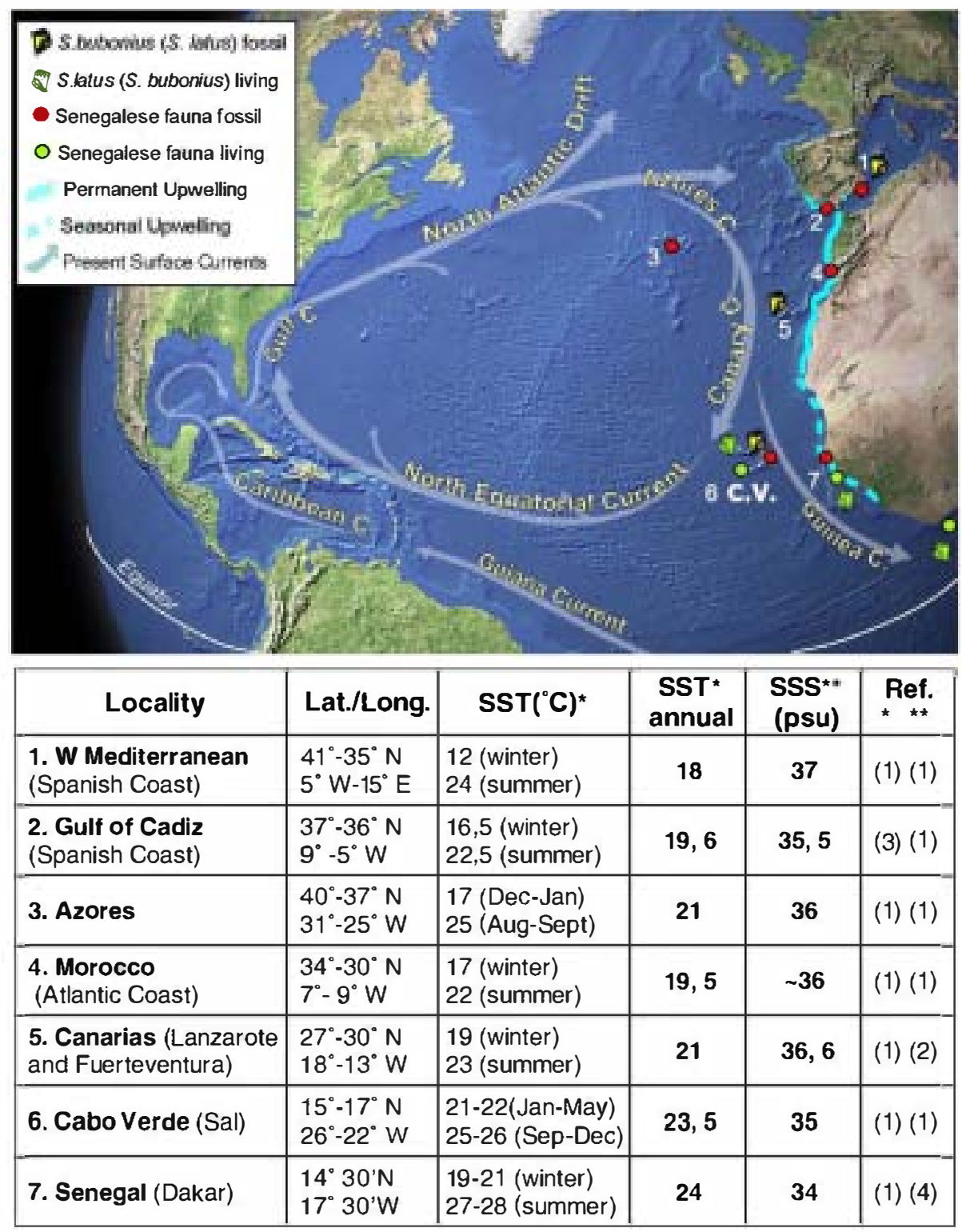

Fig. 12. Present pattern of the main superficial currents forming the North Atlantic Subtropical Gyre and distribution (present and fossil) of the warm-water "Senegalese" fauna with indication of the presence/absence of Strombus bubonius (Syn: Strombus iatus). Abbreviations in table indicate: SST: Sea Surface Temperatures, SSS: Sea Surface Salinity. Data (note asterisks) after: (1) NOAA-WOA, 2001; (2): Pelegrí et al., 2005; (3): Vargas et al, 2003; (4): Le Loeuff and Von Cosel, 1998. 
geomorphological mapping and U-Th and U-Pa measurements. These authors recorded a warm "Senegalese" fauna (Cantharus viverratus, Patella safiana, Cymatium costatum), but Strombus was apparently absent.

Lecointre (1965) cited a warm "Senegalese" fauna in Middle Pleistocene and Ouljian (last interglacial) marine terraces along the coasts of Senegal. Ouljian terraces include Cantharus viverratus and Cardita Senegalensis, i.e., species that presently survive off the West African coasts (Abbott and Dance, 2000).

Therefore, paleontological studies suggest that oceanic temperatures around the western Mediterranean, western Morocco and other Macaronesian islands during the last interglacial were higher than modern ones.

Observations in Sal Island indicate that, to survive, the warm "Senegalese" fauna needs a mean sea surface temperature (SST) of $23.5^{\circ} \mathrm{C}$, with seasonal fluctuations not exceeding $4{ }^{\circ} \mathrm{C}$ and optimum mean annual values of salinity of 35 psu (practical salinity units). Foraminifer assemblages assigned to the last interglacial in the western Mediterranean (Pérez-Folgado et al, 2004) suggest mean sea surface temperatures were $2{ }^{\circ} \mathrm{C}$ higher than modern ones, with a fresher surface layer associated with increased marine surface productivity.

Changes in the trajectory and/or strength of surface oceanic currents have certainly played a major role in carrying the larvae of the warm "Senegalese" fauna to geographically remote areas, even more than $4000 \mathrm{~km}$ away, before they reached an adult stage. Changes in oceanic currents are also related to major changes in the location of upwelling zones. These components were clearly different during the last interglacial in comparison to the present. A stronger or warmer Gulf Stream current along with a weaker Canary current might explain, at least partially, the fossil and present distribution of the warm water "Senegalese" fauna.

Additionally, it is worth noting that the faunal content of many last interglacial deposits along North American, Atlantic, and Pacific coasts (Muhs et al., 2002) seems to prove that warm waters moved a long distance northwards during MIS 5.5.

\section{Conclusions}

The present study demonstrates the need for high-resolution scale mapping of geomorphological units to reconstruct sea level changes in areas with small tectonic vertical movements. However, it also illustrates that investigations of such scale require in-depth examination of the littoral facies and their temporal and spatial reconstruction (3D stratigraphic architecture) in order to unequivocally identify sets with lateral variations of facies assembled during a single episode of sea level highstand, and to distinguish thesefromdepositsformed during distinct successive highstands or pulses inside a given highstand.

Two highstands during the last interglacial have been recorded based on geomorphological, sedimentological and stratigraphic criteria. The sea level reached elevations of $\sim 2$ masl during the older highstand, and $\sim 1.5$ masl during the younger. Smaller-scale oscillations in sea level were recorded during the late phases of the younger highstand, most likely induced by climatic changes that repeatedly modified the supply of sediment. U-series data on coral-bearing deposits allowed dating these deposits as MIS 5.5, but were not precise enough to discriminate the exact ages of the two highstands or small oscillations due to slight diagenetic U-mobility in samples.

There is a close similarity between the coasts of Sal Island and the Canary Islands with respect to relative sea level changes in the recent past, and the occurrence of MIS 5.5 deposits at low elevations. However, because the topographic elevations of MIS 5.5 deposits in both archipelagos are clearly lower than those of similar tectonic behaviour in the western Atlantic islands, further examination is required to propose plausible explanations.

Holocene deposits include beach, beach ridge and dune deposits, with variable grain size and sorting depending on both the orientation coast related to the trade winds and the proximity of the volcanic substratum that acted as source areas of the deposits. The emergent marine deposits that have been dated in Sal Island thus far are of very late Holocene age, contrary to the Canary Islands, where emergent Holocene deposits date back to the middle Holocene. This fact could be due to scarce dating or to a different response to hydroisostatic effect or both.

Combining this study with earlier investigations of the distribution of the so-called "Senegalese" warm water fauna offers new data about sea surface temperatures. It also illustrates the potential role of the superficial oceanic currents in the spreading of this fauna to other islands in the Eastern Atlantic Ocean, and as far as the Mediterranean during the last interglacial. It is also implied that the Cape Verde Archipelago was at least one of the source regions of the "Senegalese" fauna during MIS 5.

\section{Acknowledgements}

Research was financed by Spanish Projects CGL2005-01336/BTE and CGL2005-04655/BTE, by the Science and Engineering Research Council of Canada and the UNESCO Chair for Global Change Study of Université du Québèc à Montréal. Thanks to Jennifer McKay (GEOTOP) and Michel Preda (Dept. Earth \& Atmospheric Sciences, UQAM) who kindly provided analytical support, Dr. Javier Lario (Departamento de Ciencias Analíticas, Facultad de Ciencias, UNED) who calibrated a ${ }^{14} \mathrm{C}$ age, and Drs. E. Rolan and María Teresa Aparicio (Museo Nacional de Ciencias Naturales, CSIC) for identification of a terrestrial gastropod. We thank Drs. L. Ortlieb, H. Brückner and J. Rodríguez Vidal for their valuable comments and suggestions. This paper is a contribution to IGCP495 (Quaternary Land Ocean Interactions: Driving Mechanisms and Coastal Responses) and INQUA Coastal and Marine Processes.

The authors wish to pay a special tribute to Prof. H. Faure whose personality and leading spirit greatly influenced our research. No thanks will ever express our gratitude.

\section{References}

Abbott, R.T., Dance, S.P., 2000. Compendium of seashells. Odyssey Publishing, El Cajón, California. $411 \mathrm{pp}$

Alouane, M. 2001. Les formations quaternaires des secteurs littoraux du Maroc septentrional (régions de Tanger et de Nador): analyse morpho-structurale, lithostratigraphique et sédimentologique. Ph.D. thesis. Universitê Mohammed V-Agdal Facultê des Sciences. Rabat, Maroc.

Avila, S.P., 2000. Shallow-water marine molluscs of the Azores: biogeographical relationships. Archipelago. Life and Marine Sciences 2 (Part A), 99-131.

Avila, S.P., Amen, R., Azevedo, J.M.N., Cachão, M., García-Talavera, F., 2002. Checklist of the Pleistocene marine molluscs of Prainha and Lagoinhas (Santa Maria Island, Azores). Acoreana 9 (4), 343-370.

Avila, S.P., Madeira, P., Mendes, N., Rebelo, A, Medeiros, A, Gomes, C, García-Talavera, F., Marques da Silva, C, Cachão, M., Hillaire-Marcel, C., de Frias Martins, A.M., 2008. Mass extinctions in the Azores during the last glaciation: fact or myth? Journal of Biogeography. doi:10.1111/j.1365-2699.2008.01881.x.

Brebion, P.H., Ortlieb, L., 1976. Nouvelles Recherches Géologiques et malacologiques sur le Quaternaire de la province de Tarfaya (Maroc Méridional). Geobios 9 (5), 529-550.

Brückner, H., 1986. Stratigraphy, evolution and age of Quaternary marine terraces in Morocco and Spain. Zeitschrift für Geomorphologie N.F. (62), 83-101.

Callapez, P., Ferreira Soares, A, 2000. Late Quaternary warm marine molluscs from Santa Maria (Azores) paleoecologic and palaeobiogeographic considerations. Ciéncias da Terra (UNL) 14, 313-322.

Chen,J.H., Curran, H.A., White, B., Wasserburg, G.J., 1991. Precise chronology of the last interglacial period: $234 \mathrm{U}-230 \mathrm{Th}$ data from fossil coral reefs in the Bahamas. Geological Society of America Bulletin 103, 82-97.

Cuerda, J., 1989. Los tiempos cuaternarios de las Baleares. Dir. Gral. Cultura. Conselleria de Cultura, Educació i Esports. Govern Balear, Mallorca, Spain.

Davies, T.T., Hooper, P.R., 1963. The determination of the calcite/aragonite ratio in mollusc shells by X-ray diffraction. Mineralogical Magazine 33, 608-612.

Dumas, B., Hoang, C.T., Raffy, J., 2006. Record of MIS 5 sea-level highstands based on U/ Th dated coral terraces of Haiti. Quaternary International 145-146, 106-118.

Edwards, R.L., Chen, J.H., Wasserburg, G.J., 1987. 238U-234U-230Th-232Th systematics and the precise measurements of time over the past 500,000 years. Earth and Planetary Science Letters $81,175-192$.

García-Talavera, F., 1987. Fauna tropical en el Neotirreniense de Santa Maria (I. Azores). Labori S.I.M. 23, 439-443. 
García-Talavera, F., 1999. Fauna malacológica del cuaternario marino de Cabo Verde 1999. Fauna malacológica del cuaternario marino de Cabo Verde. RevistaAcademia Canaria de las Ciencias XI (3-4), 9-25.

García-Talavera, F., Sánchez-Pinto, L., 2002. Moluscos marinos fósiles de Selvagem Pequenha e Ilheu de Fora (Islas Salvajes). Descripción de una nueva especie de Neogasterópodo. Revista Academia Canaria de las Ciencias XIII (9-21), 9-21.

Gignoux, M., 1913. Les formations marines pliocènes et quaternaires de I'Italie du sud et de la Sicile: Annals Universitê de Lyon, vol. 36.

Goy, J.L., Zazo, C., Barda jí, T., Somoza, L., Causse, C., Hillaire-Marcel, C., 1993. Elêments d'une chronostratigraphie du Tyrrhénien des régions d'Alicante-Murcia, Sud-est de I'Espagne. Geodinamica Acta 6 (2), 103-119.

Hearty, P.J., 1987. New data on the Pleistocene of Mallorca. Quatemary Science Reviews 6 , 254-257.

Hearty, P.J., 2002. Revision of the late Pleistocene stratigraphy of Bermuda. Sedimentary Geology 153, 1-21.

Hearty, P.J, Kaufman, D.S., 2000. Whole-rock aminostratigraphy and Quaternary sealevel history of the Bahamas. Quaternary Research 54, 163-173.

Hillaire-Marcel, Cl., Gariepy, Cl., Ghaleb, B., Goy, J.L., Zazo, C., Cuerda, J., 1996. U-series measurements in Tyrrhenian deposits from Mallorca. Furtherevidente for two LastInterglacial high sea-levels in the Balearic Islands. Quaternary Science Reviews 15 $53-62$.

Hoang, C.T., Ortlieb, L., Weisrock, A., 1978. Nouvelles datations ${ }^{23} \mathrm{Th} /{ }^{234} \mathrm{U}$ de terrasses marines "ouljiennes" du sud-ouest du Maroc et leurs significations stratigraphique et tectonique. Compte Rendue de I'Académie de Sciences. Paris 286, 1759-1762.

IsseI, A., 1914. Iembi fossiliferi quaternari e resentí nella Sardegna meridionale. Accademia Nazionale dei Lincei, Serie 5-23, 759-770.

Kaufman, A, Ghaleb, B., Wehmiller, J.F., Hillaire-Marcel, C., 1996. Uranium concentra tion and isotope ratio profiles within Mercenaria shells: Geochronologica implications. Geochimica et Cosmochimica Acta 60 (19), 3735-3746.

Lario,J.,Zazo, C., Somoza, L., Goy, J.L., Hoyos, M., Silva, P.G., Hernández-Molina, F.J., 1993. Ios episodios marinos cuaternarios de la costa de Málaga (España). Revista de la Sociedad Geológica de España 6 (3), 41-46.

Ie Loeuff, P., Von Cosel, R., 1998. Biodiversity patterns of the marine benthic fauna on the Atlantic coast of tropical Africa in relation to hydroclimatic conditions and paleogeographic events. Acta Oecologica 19, 309-321.

Iecointre, G., 1962. Le Quaternaire de I'île de Sal (archipel du Cap-Vert). Compte Rendue Sommaire des Sêances Sociêtê Géologique de France, pp. 3-92.

Lecointre, G., 1963. Sur les terrains sédimentaires de lî̀le de Sal. Avec Remarque sur les isles de Santiago et Maio (Archipel du Cap Vert). García de Orta, Serie de Geologia, lisboa, vol. II, (2), pp. 275-289.

Iecointre, G., 1965. Le Quaternaire marin de I'Afrique du nord-ouest. Quaternaria VII, 9-28.

Meco, J., Petit-Maire, N., Fontugne, M., Shimmield, G., Raoms, A.J., 1997. The quaternary deposits in Lanzarote and Fuerteventura (eastern Canary Islands, Spain): and overview In: Meco, J Petit-Maire N. (Eds). Climates of the Past. IUGS-UNESCOUniversidad de las Palmas de Gran Canaria, Las Palmas de Gran Canaria, pp. 123-136

Meco, J., Gillou, H., Carracedo, J.C., Lomoschitz, A., Ramos, A.J.G., Rodríguez-Yánez, J.J. 2002. The maximum warmings of the Pleistocene world climate recorded in the Canary Islands. Palaeogeography, Palaeoclimatology, Palaeoecology 185, 197-210

Morri, C., Bianchi, C.N., 1995. Ecological niches of hermatypic corals at Ilha do Sal (Archipelago de Cabo Verde). Boletin do Museu Municipal de Funchal, Madeira, Sup. $n^{\circ} 4$, pp. $473-485$

Morri, C.R., Cattaeno-Vietti, G., Sartoni, G., Banchi, N., 2000. Shallow epibenthic communities of Ilha do Sal (Cape Verde Archipelago, eastem Atlantic). Arquipêlago. life and Marine Sciences, Ponta Delgada.Açores, Supplement 2 (Part A), pp. 157-165

Muhs, D.R., 2002. Evidence for the timing and duration of the Last Interglacial period from high-precision uranium-series ages of corals on tectonically stable coastlines. Quaternary Research 58, 36-40.

Muhs, D.R., Simmons, K.R., Steinke, B., 2002. Timing and warmth of the last interglacial period: new U-series evidence from Hawaii and Bermuda and a new fossil compilation for North America. Quaternary Science Reviews 21, 1355-1383.

Mylroie, J.E., 2007. Late Quaternary sea level position: evidence from Bahamian carbonate deposition and dissolution cycles. Quaternary International. doi:10.1016/ j.quaint.2007.06.030

Neumann, AC., Hearty, P.J., 1996. Rapid sea-level changes at the close of the last interglacial (substage 5e) recorded in the Bahamian island geology. Geology 24 (9), $775-778$

NOAA-WOA, 2001. http://iridl.ldeo.columbia.edu/SOURCES/.NOAA/.NODC/.WOA01.

Occhietti, S., Raynal, J.P., Pichet, P., Lefèvre, D., 2002. Aminostratographie des formations littorals plêistocènes et holocènes de la region de Casablanca, Maroc. Quaternaire 13 . $55-64$.

Pelegrí,J.L., Arístegui, J., Cana, L., González-Dávila, M., Hemández-Guerra, A., HernándezIeón, S., Marrero-Díaz, A., Montero, M.F., Sangrã, P., Santana-Casiano, M., 2005.
Coupling between the open ocean and the coastal upwelling region off northwest Africa: water recirculation and of fshore pumping of organic matter. Journal of Marine Systems 54, 3-37.

Pérez-Folgado, M., Sierro, F.J., Flores, J.A., Grimalt, J.O., Zahn, R., 2004. Paleoclimatic variations in foraminifer assemblages from the Alboran Sea (Western Mediterranean) during the Last $150 \mathrm{ka}$ in ODP site 977. Marine Geology 212, 113-131.

Plaziat, J.C., Reyss, J.L., Choukri, A., Orsag-Sperber, F., Baltzer, F., Purser, B.H., 1998. Mise en êvidence, sur la côte récifale d'Egypte, d'une régressioninterrompant brièvement le plus haut niveau du Dernier Interglaciaire: un nouvel indice de variations glacioeustatiques ã haute fréquence au Pléistocène? Bulletin de la Société Géologique de France 169 (1), 115-125

Schellmann, G., Radtke, U., 2004. A revised morpho- and chronostratigraphy of the Late and Middle Pleistocene coral reef terraces on Southern Barbados (West Indies) Earth-Science Reviews 64, 157-187.

Schellmann, G., Radtke, U., Potter, E.-K., Esat, T.M., McCulloch, M.T., 2004 Comparison of ESR and TIMS U/Th dating of marine isotope stage (MIS) 5e, 5c, and $5 a$ coral from Barbados-implications for palaeo sea-level changes in the Caribbean. Quaternary International 120, 41-50.

Silva, L., Torres, P., Figueiredo, M.O., Palacios, T., 1993. Fosfatização de rochas basálticas da ilha do Sal, archipélago de Cabo Verde. Garcia de Orta, Serie de Geologia, Lisboa $15(1-2), 1-22$.

Stearns, C.E., Thurber, D.L., 1965. Th 230-UTh 234 dates of late Pleistocene marine fossils from the Mediterranean and Moroccan littorals. Quaternaria VII, 29-42.

Stirling, C.H., Esat, T.M., Lambeck, K., McCulloch, M.T., 1998. Timing and duration of the last Interglacial: evidence for a restricted interval of widespread coral reef growth Earth and Planetary Science Ietters 160, 745-762.

Stuiver, M., Braziunas, P., 1993. $14 \mathrm{C}$ ages of marine samples to $10,000 \mathrm{BC}$ yr BP. Radiocarbon 35 (1), 137-189.

Stuiver, M., Reimer, P., 1993. Extended ${ }^{14} \mathrm{C}$ data base and revised CALIB $3.0{ }^{14} \mathrm{C}$ calibration program. Radiocarbon 35, 231-237.

Thompson, W.G., Spiegelman, M.W., Goldstein, S.L., Speed, R.C., 2004. An open-system model for U-series age determinations of fossils corals. Earth and Planetary Science Letters 210, 365-381.

Torres, P.C, Silva, L.C., Serralheiro, A, Tassinari, C., Munhá, J., 2002a. Enquadramento geocronológico pelo método $\mathrm{K} / \mathrm{Ar}$ das principais sequèncias vulcano-estratigráficas da Ilha do Sal-Cabo Verde. Garcia de Orta, Serie de Geologia, Lisboa 18 (1-2).

Torres, P.C., Silva, L.C, Srealheiro, A., Mendes, M.H., Macedo, J., Mote Gomes, A., 2002b. Geologia da Ilha do Sal Serie de Ciencias da Terra 10, 1-572 Geological Sheets I-Il.

Vargas, J.M., García-Lafuente, J., Delgado, J., Criado, F., 2003. Seasonal wind-induced variability of Sea Surface Temperature patterns in the Gulf of Cádiz. Journal of Marine Systems 38, 205-219.

Wehmiller,J.F., Simmons, K.R., Cheng, H., Edwards, R.L., Martin-McNaughton, J., York, L.L., Krantz, D.E., Shen, C-C., 2004. Uranium-series coral age from the US Atlantic Coastal plain. The "80 ka problem" revisisted. Quatemary Intemational 120, 3-14.

Weisrock, A., Occhietti, S., Hoang, C.T., Lauriat-Rage, A., Brêbion, P., Pichet, P., 1999. Les sequences littorals pléistocènes de I'Atlas atlantique entre Cap Rhir et Agadir, Maroc. Quaternaire 10 (2-3), 227-244.

Zazo,C., Silva,P.G., Goy, J.L., Hillaire-Marcel, C., Ghaleb, B., Lario, J., Bardaji, T., González, A, 1999. Coastal uplift in continental collision plate boundaries: data from the Last Interglacial marine terraces of the Gibraltar Strait area (south Spain). Tectonophysics 301, 95-109.

Zazo,C., Goy,J.L., Hillaire-Marcel, Cl, Gillot, P.Y., Soler,V., González,J.A., Dabrio, C J., Ghaleb, B., 2002. Raised marine sequences of Lanzarote and Fuerteventura revisited-a reappraisal of relative sea-level changes and vertical movements in the eastern Canary Island during the Quaternary. Quaternary Science Reviews 21, 2019-2046.

Zazo, C., Goy, J.L., Dabrio, C.J., Bardaji, T., Hillaire-Marcel, Cl., Ghaleb, B., González, J.A., Soler, V., 2003. Pleistocene raised marine terraces of the Spanish Mediterranean and Atlantic coasts: records of coastal uplift, sea-level highstands and climate changes. Marine Geology 194, 103-133.

Zazo, C., Goy, J.L., Barda jí, T., González, J.A., Hillaire-MarceI, Cl., Dabrio, C.J., Lario, J., Civis, J, Luque, L., Ghaleb, B., Bor ja, F. Silva, P.G., González-Hernández, F., Soler, V., Gillot, P.Y 2004. El efecto de los ciclos climátioos en las variaciones del nivel del mar. In: Baquedano, E., Rubio, S. (Eds.), Miscelánea en Homena je a Emiliano Aguirre: Geología, Museo Arqueológico Regional, Alcalá de Henares, vol. I, pp. 156-167.

Zazo, C, Goy, J.L., González, J.A., Hillaire-Marcel, Cl., Dabrio, C. J., Bardaji, T., Cabero, A. Ghaleb, B., Lario, J., Liqque, L., Silva, P.G., Soler, V., Gillot, P.Y., 2005. Las terrazas marinas de los iltimos $140 \mathrm{ka}$, como geo-bio marcadores de la inestabilidad climática y del nivel del mar: archipiêlagos de Cabo Verde y Canarias. In: Hernández, L., Alonso, I., Mangas, J., Yanes, A. (Eds.), Tendencias actuales en Geomorfología litoral. Universidad de Las Palmas de Gran Canaria, pp. 181-185.

Zazo, C., Goy, J.L., Dabrio, C. J., Soler, V., Hillaire-Marcel, C, Ghaleb, B., González-Delgado, J.A., Barda jí, T., Cabero, A., 2007. Quaternary marine terraces on Sal Island (Cape Verde archipelago). Quaternary Science Reviews 26, 876-893. 